\title{
Любовь к ботанике
}

\author{
С. А. Сенатор ${ }^{1 凶}$, А.Я. Григорьевская ${ }^{2}$ \\ ${ }^{1}$ Главный ботанический сад им. Н. В. Цищина Российской академии наук, Российская Федерация \\ (127276, г. Москва, ул. Ботаническая, 4) \\ ${ }^{2}$ Воронежский государственный университет, Российская Федерация \\ (394018, г. Воронеж, Университетская пл., 1)
}

\begin{abstract}
Аннотация: В статье приводится информация о научной деятельности ученого-ботаника, доктора биологических наук, профессора, заслуженного деятеля науки РФ, члена президиума Русского ботанического общества С.В. Саксонова. Им впервые для науки описано несколько видов сосудистых растений, основаны научные журналы ботанического и экологического профиля, создана традиция проведения экспедиций-конференций по изучению растительного покрова Среднего Поволжья. С. В. Саксонов внес большой вклад в развитие гербарного дела.
\end{abstract}

Ключевые слова: флора, фиторазнообразие, гербарий, редкие растения.

Для цитирования: Сенатор С. А., Григорьевская А. Я. Любовь к ботанике // Вестник Воронежского государственного университета. Серия: География. Геоэкология, 2021 № 4, с. 106-108. DOI: https:// doi.org/10.17308/geo.2021.4/3757

Получить представление об огромном потенциале фиторазнообразия Земли и выявить закономерности его развития возможно только на научной основе. Сергей Владимирович Саксонов внес большой вклад в науку о растениях. Это известный российский ботаник, эколог, организатор науки, член президиума Русского ботанического общества (с 2013 г.), основательипервыйпредседатель Тольяттинскогоотделения Русского ботанического общества (с 2008 г.), член Природоохранительной комиссии Русского географического общества, Териологического общества при РАН (с 1986 г.), Московского общества испытателей природы (с 1988 г.). С 2003 г. являлся академиком Международной академии наук экологии и безопасности жизнедеятельности. С. В. Саксонов неоднократно награждался премиями и почетными грамотами Самарской области за заслуги в области науки и охраны природы. За вклад в развитие региональной экологии награжден в 2007 г. медалью имени В.А. Легасова, за природоохранную деятельность - знаком «За заслуги в заповедном деле» Минприроды России.

Охрана природы с особым вниманием к редкой и реликтовой фитобиоте - пожалуй, центральное направление научной деятельности С.В. Саксонова, что подтверждено многочисленными публика- циями в ведущих научных журналах. В частности, им подробно описаны критерии организации особо охраняемых природных объектов, разработана системная концепция их мониторинга, рассмотрены юридические моменты организации деятельности природопользователей в местах концентрации охраняемой биоты, впервые создана классификация категорий статуса редких видов растений.

Важным направлением работы Сергея Владимировича стали вопросы приспособления флоры к динамичным условиям среды обитания. Движущими силами этих процессов являются угасание и выбывание из видового спектра одних таксонов, возникновение новых в ходе видообразования и внедрение пришлых элементов, прежде отсутствующих в исследуемой флоре. Сделан особый акцент на необходимости регулярных и долговременных мониторинговых наблюдений за растениями на объектах охраны. С.В. Саксонов сформулировал гипотезу, что исчезновение из видового состава отдельных его элементов идет постоянно и является нормальным явлением. Анализ «выпавших» из флоры таксонов должен проводиться на базе дифференциированного подхода - в зависимости от биологии, экологии видов и особенностей их ареалов, а также даты их последней встречи.

(C) Сенатор С.А., Григорьевская А. Я., 2021

$\triangle$ Сенатор Степан Александрович, e-mail: senator@gbsad.ru

Контент доступен под лицензией Creative Commons Attribution 4.0 License. 
Сергей Владимирович обращал внимание на необходимость охраны не только редких видов, но и более распространенных растений, не входящих в охранные списки. Для этого следует вести систематический и регулярный учет видового состава, исследовать таксономические характеристики и оценивать влияние эколого-ценотических особенностей среды на произрастание растений. Сергеем Владимировичем обоснована необходимость создания кадастра раритетных таксонов территории бассейна Волги с осмыслением ключевых принципов и методов его составления. Издание списков редких и находящихся под угрозой исчезновения сосудистых растений крупных естественно-исторических выделов должно связывать между собой сведения Красной книги Российской Федерации, региональных охранных списков и Красного списка находящихся под угрозой видов Международного союза охраны природы. Реализация этой идеи увеличит эффективность взаимодействия государственных органов, общественности и коммерческих структур в решении проблемы стабилизации и воссоздания естественного биоразнообразия макрорегионов Земли, скоординирует деятельность региональных групп специалистов-ботаников, ускорит разработку и внедрение мероприятий по сохранению раритетной фитобиоты на всех уровнях.

В работах Сергея Владимировича большое внимание уделялось созданию системы флористического мониторинга с постановкой целей и задач, определением этапов, разработкой принципов и методов оптимальной организации долговременных наблюдений за состоянием биоты, учитывая влияние антропогенной деятельности и постоянной динамики природных факторов.

Сергей Владимирович продвигал идею сохранения и развития гербарных коллекций. Он подчеркивал важность небольших региональных гербариев, призывал к ответственному подходу при хранении гербарного материала, постоянному пополнению фондов новыми сборами, использованию современных методов информационных технологий для популяризации ботанических знаний. С.В. Саксонов также освещал этические и правовые аспекты работы коллектора на объектах с ценной и охраняемой биотой. По его инициативе в 2015 г. в г. Пенза была проведена Всероссийская научная конференция с международным участием «Ботанические коллекции России - национальное достояние», посвященная 120-летию Гербария им. И. И. Спрыгина и 100-летию Русского ботанического общества. Основными целями этого мероприятия стали обмен опытом ведения гербарных коллекций, осознание роли гербариев в повышении научного, культурного и образовательного уровня населения, содействие внедрению передовых цифровых и интеллектуальных технологий в этой области, а также объединение усилий в борьбе за будущее «больших» и «малых» ботанических коллекций. На этой конференции Кафедра ЮНЕСКО «Изучение и сохранение биологического разнообразия Волжского бассейна» признала национальным достоянием России Гербарий факультета географии, геоэкологии и туризма Воронежского государственного университета (VORG).

Следует подчеркнуть огромные заслуги Cергея Владимировича в издательском деле. Он совместно с коллегами организовал ряд известных периодических научных изданий. Так, в 1991 г. его трудами был основан экологический журнал «Самарская Лука: проблемы региональной и глобальной экологии», а в 2006 г. - журнал ботанического профиля «Фиторазнообразие Восточной Европы». С 2009 г. выходит научно-популярная ботаническая интернет-газета «Flora foliumii». С.В. Саксонов заложил традицию проведения уникальных полевых экспедиций-конференций, которые стали основой для создания научной школы флористики Среднего Поволжья. Первая подобная экспедиция была проведена в 1999 г., последняя - в 2020 г. Результаты многолетней работы экспедиций-конференций опубликованы в научных статьях и монографиях по флоре Среднего Поволжья, содержащих описание новых для науки таксонов и интересных номенклатурных комбинаций. Изучение флоры Волжского бассейна тесно связано с флористическим мониторингом, охраной редких растений, организацией ООПТ федерального и регионального уровней.

Преподавательская работа С.В. Саксонова в Самарском и Тольяттинском государственном университетах способствовала прививанию молодым исследователям любви к флористике.

Научная деятельность С. В. Саксонова связана с решением фундаментальных проблем флористики и региональной экологии, сохранения фиторазнообразия на особо охраняемых природных территориях. Его талант организатора проявился при проведении научных конференций, издательской и редакторской деятельности. Его творческое наследие заключено в 900 научных трудах, в числе которых 65 монографий, 15 учебников, методических и учебных пособий. С.В. Саксонов являлся научным руководителем при написании 13 кандидатских и 3 докторских диссертаций в области биологических наук. 
Сергей Владимирович Саксонов был истинным ученым, человеком с большой буквы - ответственным, порядочным, трудолюбивым, отзывчивым, справедливым и глубоко уважаемым его близкими и коллегами. В то же время Сергей Владимирович не был лишен твердого характера и лидерских качеств, что помогало ему, помимо научных занятий, вести активную организаторскую деятельность и достигать в ней больших высот. Память о С. В. Саксонове сохранится в его делах, работах, учениках и моментах общения с ним.

Конфликт интересов: Авторы декларируют отсутствие явных и потенциальных конфликтов интересов, связанных с публикацией настоящей статьи.

Поступила в редакциию 12.11.2021

Принята к публикации 23.11.2021

DOI: https://doi.org/10.17308/geo.2021.4/3757

\title{
Love for Botany
}

\author{
S.A. Senator ${ }^{1}$, A. Ya. Grigor'evskaya ${ }^{2}$ \\ ${ }^{I}$ Tsitsin Main Botanical Garden of the Russian Academy of Sciences, Russian Federation \\ (4, Botanicheskaya Str., Moscow, 127276) \\ ${ }^{2}$ Voronezh State University, Russian Federation \\ (1, Universitetskaya Sq., Voronezh, 394018)
}

\begin{abstract}
The article provides information about scientific activities of the scientist-botanist, Doctor of Biological Sciences, Professor, Honoured Scientist of the Russian Federation, member of the Presidium of the Russian Botanical Society S.V. Saksonov. He described several new species of vascular plants, founded new scientific journals of botanical and ecological profile and created a tradition of expedition-conferences on studying the vegetation of the Middle Volga region. S.V. Saksonov made a great contribution to the development of herbarium work.
\end{abstract}

Key words: flora, phytodiversity, herbarium, rare plants.

For citation: Senator S.A., Grigor'evskaya A. Ya. Love for Botany. Vestnik Voronezskogo gosudarstvennogo universiteta. Seria: Geografia geoekologia, 2021, no. 4, pp. 106-108 (In Russ.) DOI: https://doi.org/10.17308/ geo.2021.4/3757

Conflict of interest: The authors declare no information of obvious and potential conflicts of interest related to the publication of this article.

Received: 12.11 .2021

Accepted: 23.11.2021

Сенатор Степан Александрович

кандидат биологических наук, заместитель директора по научной работе Главного ботанического сада им. Н.В. Цицина Российской академии наук, г. Москва, Российская Федерация, ORCID: 0000-0003-1932-2475, e-mail: senator@gbsad.ru

Григорьевская Анна Яковлевна

доктор географических наук, кандидат биологических наук, профессор кафедры геоэкологии и мониторинга окружающей среды, факультет географии, геоэкологии и туризма, Воронежский государственный университет, г. Воронеж,Российская Федерация, ORCID: 0000-00024342-9566, e-mail: grigaya@mail.ru

\section{Stepan A. Senator}

Cand. Sci. (Biol.), Deputy Director for Science, Tsitsin Main Botanical Garden of the Russian Academy of Sciences, Moscow, Russian Federation, ORCID: 0000-00031932-2475, e-mail: senator@gbsad.ru

\section{Anna Ya. Grigor'evskaya}

Dr. Sci. (Geogr.), Cand. Sci. (Biol.), Professor, Department of Nature Management and Conservation, Faculty of Geography, Geo-ecology and Tourism, Voronezh State University, Voronezh, Russian Federation, ORCID: 00000002-4342-9566, e-mail: grigaya@mail.ru

(C) Senator S.A., Grigor'evskaya A. Ya., 2021

$\bowtie$ Stepan A. Senator, e-mail: senator@gbsad.ru

The content is available under Creative Commons Attribution 4.0 License. 